\title{
A double blind multicentre study of OM-8980 and auranofin in rheumatoid arthritis
}

\author{
T L VISCHER* \\ From the Hôpital Cantonal Universitaire, $\mathrm{CH}-1211$, Geneva, Switzerland*
}

SUMMARY The therapeutic efficacy of the immunomodulator OM-8980 in rheumatoid arthritisi was compared with that of auranofin, an oral gold salt, in a double blind, randomised multicentre study lasting six months. Seventy patients were treated with auranofin and 75 with OM-8980. The patients of both groups improved significantly at three and six months for all the clinicab parameters observed: Ritchie index, number of swollen joints, morning stiffness, pain, grip strength, intake of non-steroidal anti-inflammatory drugs, and erythrocyte sedimentation rate $\bigcirc$ No serious side effects were observed in either group. The patients receiving auranofin had moreadverse reactions, mainly affecting the gastrointestinal system.

Key words: disease modifying drugs.

Disease modifying drugs used in rheumatoid arthritis (RA) are relatively toxic and their use requires close surveillance of the patients. In a small pilot study it was suggested that OM-8980, a lyophilised, lipopolysaccharide free extract from Escherichia coli, has disease modifying activity in RA combined with a good tolerance. ${ }^{1}$ As similar extracts have already been widely used as immunostimulants for the non-specific treatment and prevention of bronchitis, ${ }^{2} 3$ without causing any serious side effects, OM- 8980 could become a relatively nontoxic, slow acting drug for RA. In a multicentre study of ambulatory patients with RA we therefore compared OM-8980 with auranofin, ${ }^{4}$ an oral gold preparation that has recently been introduced in several European countries and the USA.

\section{Patients and methods}

PAT IEN TS

Adult outpatients were admitted with definite or classical rheumatoid arthritis as defined by the

Accepted for publication 2 January 1988.

Correspondence to Professor T L Vischer, Hôpital Cantonal Universitaire, $\mathrm{CH}-1211$, Geneva, Switzerland.

${ }^{*}$ Nineteen other physicians from Germany and Switzerland took part in the study: I Bahous, Basle; H Baumgartner, Zurich; I Boussina, Geneva; D Brackertz, Mainz; Y Chichakli, Kelsterbach; K Hess, Hanover; J Kandziora, Troisdorf; H Keller, Oberursell; R Kemmer, Cologne; K Miehlke, Wiesbaden; U Mosimann, Thun; A S Omar, Wiesbaden; H Ott, La Chaux-De-Fonds; B Radanowicz, Basle; U Schlumpf, Lucerne; K Schmidt, Bad Nauheim; G Ströbel, Wuppertal; H J Taenzer, Cologne; H Zeidler, Dusseldorf.
American Rheumatism Association criteria, ${ }^{5}$ an active disease. RA was considered active when the Ritchie index ${ }^{6}$ was $>15$, morning stiffness laste $>45$ minutes, and when the erythrocyte sedimenta $\mathbb{D}$ tion rate (ESR) was $>30 \mathrm{~mm} / \mathrm{h}$. Patients in func $\overrightarrow{\vec{B}}$ tional stage 4 , or who suffered from another disease which could have interfered with the trial, were excluded. Known intolerance to gold salts, prege nancy, and lack of contraception in women in the childbearing age were further reasons for exclusiono The treatment with slow acting antirheumatic druge (such as gold, D-penicillamine, antimalarial drugs and immunosuppressive drugs, etc) had to be stopped for at least three months before the begin ning of the trial. Corticosteroids were limited to the equivalent of $10 \mathrm{mg} /$ day of prednisone. At the start of the study seven patients took a mean of $6 \mathrm{mg}$ o. prednisolone in the auranofin group and five patients a mean of $4 \mathrm{mg}$ in the OM-8980 group. Patients continued to take the previous analgesic oD anti-inflammatory drugs.

STUDY DESIGN

OM-8980 (OM Laboratories, Meyrin/Geneva $\stackrel{0}{\frac{0}{1}}$ Switzerland) is prepared from the biomass of $E$ col $[?$ cultures by extraction and subsequent purification;o resulting in proteinic macromolecules without de $\overrightarrow{0}$ tectable lipopolysaccharide. Each capsule of the drug contains $24 \mathrm{mg}$ of the immunomodulatory fractions. Having given informed consent, the selected patients were allocated to one of two treatment groups according to a centrally prepare 
randomisation list. They were treated daily under double blind conditions for six months with either OM-8980 or auranofin ( $3 \mathrm{mg} /$ capsule). For the first 10 days the patients took in the morning, on an empty stomach, one orange capsule containing either OM-8980 or auranofin, then until the end of the sixth month, in addition to the orange morning capsule, one white capsule before the evening meal containing a placebo for the OM-8980 group and auranofin for the auranofin group.

CLINICAL AND BIOLOGICAL ASSESSMENTS Patients were examined each month by their physician, with a complete evaluation at the start of the study and after three and six months. Mandatory clinical assessments were Ritchie index ${ }^{6}$ the number of swollen joints, grip strength, pain measured by Huskisson's visual analogue scale, ${ }^{7}$ duration of morning stiffness, and intake of antiinflammatory drugs. ESR, leucocytes, thrombocytes, and haemoglobin were determined monthly, and every three months an extensive toxicology screen was carried out, including liver and kidney functions. In addition, serum samples were frozen for central determination of rheumatoid factor with the latex fixation test ${ }^{8} \mathrm{Clq}$ binding test, ${ }^{9} \mathrm{C}$ reactive protein (CRP), cytidine deaminase $,{ }^{10} \mathrm{IgG}, \mathrm{IgM}, \alpha_{2}$ macroglobulin, albumin, and $\alpha_{1}$ antiproteinase (by immunodiffusion using the $\mathrm{F}(\mathrm{ab})_{2}$ fragments of specific antibodies ${ }^{11}$ ).

\section{STATISTICAL METHODS}

Before the start of the study the necessary number of patients was estimated to be about 150 on the assumption that a $15 \%$ difference in the Ritchie index between the two treatments should be detected, with the standard deviation set at $40 \%$, the $\alpha$ error at 0.05 , and the $\beta$ error at $0 \cdot 1$. All data were recorded on standard record forms and submitted for independent statistical analysis (WirtschaftsMathematik AG, Zurich). For statistical evaluation of intragroup and intergroup differences the changes in the clinical parameters used to assess efficacy were calculated according to the method of Lewi and Symoens ${ }^{12}$ as relative percentual differences. For intragroup comparisons the $t$ test for paired samples was used for the Ritchie index, the number of swollen joints, and the ESR; the Wilcoxon test for paired samples for the pain scale, duration of morning stiffness, and grip strength. For intergroup comparisons the $t$ test was used for the Ritchie index, the number of swollen joints, and the ESR; the Mann-Whitney test for the pain scale, duration of morning stiffness, and grip strength. The protocol had been approved by the ethical committee of the department of medicine, University of Geneva.

\section{Results}

\section{PATIENTS}

One hundred and forty six patients entered the study (Table 1). Twenty centres participated in the trial (mean 7.25 patients a centre, range 1-22). Fifty seven patients in the OM-8980 group and 54 patients in the auranofin group came from eight centres with eight or more patients. For analysis all patients were taken together. One patient dropped out during the first month and was excluded. One hundred and forty five patients, 75 treated with OM-8980 and 70 with auranofin, were thus considered for the statistical analysis. Two patients withdrawn only during the last month were included in the six month evaluation. Table 1 shows a further 15 withdrawals in each treatment group for different reasons, leaving 117 patients for the final assessment (including the two cases mentioned above). The characteristics of the patients were similar in both groups except for age, which was slightly but significantly higher in the group treated with auranofin

Table 1 Number of patients included in the trial and reasons for withdrawal

\begin{tabular}{lccc}
\hline & $O M-8980$ & Auranofin & Total \\
\hline $\begin{array}{l}\text { At entry } \\
\text { At month 6: }\end{array}$ & 76 & 70 & 146 \\
$\quad \begin{array}{l}\text { Evaluated } \\
\text { Withdrawal for inefficacy }\end{array}$ & 3 & 56 & 117 \\
$\begin{array}{l}\text { Withdrawal for adverse } \\
\text { reaction }\end{array}$ & 8 & $4 \dagger$ & $7 \dagger$ \\
$\quad \begin{array}{l}\text { Withdrawal for unrelated } \\
\text { reasons }\end{array}$ & $4 \ddagger$ & $9 \dagger$ & $17 \dagger$ \\
\hline
\end{tabular}

*Two patients withdrawn during the last month were included in the six month evaluation.

+Withdrawal of one patient for two reasons.

‡Protocol violation (one patient), moved (one), intercurrent disease (one), non-attendance (one).

§Intercurrent disease (two).

Table 2 Characteristics of the patients

\begin{tabular}{lll}
\hline & $\begin{array}{l}\text { OM-8980 } \\
(n=75)\end{array}$ & $\begin{array}{l}\text { Auranofin } \\
(n=70)\end{array}$ \\
\hline $\begin{array}{l}\text { Women (No (\%)) } \\
\text { Age (years, mean } \\
\text { (SD); median) }\end{array}$ & $54(72)$ & $45(64)$ \\
$\begin{array}{l}\text { Duration of disease } \\
\text { (years, mean (SD); } \\
\text { median) }\end{array}$ & $52 \cdot 7(14 \cdot 8) ; 53 \cdot 0$ & $58 \cdot 4(13 \cdot 1) ; 57 \cdot 0^{*}$ \\
$\begin{array}{c}\text { Positive rheumatoid } \\
\text { factor (No (\%)) }\end{array}$ & $50(7 \cdot 36) ; 6 \cdot 0$ & $8 \cdot 5(7 \cdot 03) ; 6.5$ \\
$\begin{array}{c}\text { Previous slow acting } \\
\text { antirheumatic drugs } \\
\text { (No (\%)) }\end{array}$ & $28(37)$ & $47(67)$ \\
\hline
\end{tabular}

${ }^{*} \mathrm{p}<0.05, \chi^{2}$ test. 
(Table 2). At the start of the study the clinical variables monitored for evaluation of efficacy and the biological parameters were comparable in both groups (Table 3).

\section{RESPONSE TO TREATMENT}

Tables 3 and 4 and Fig. 1 show that both groups improved significantly at month 3 and even more at month 6 for all the clinical variables in comparison with the respective prestudy values. There were no relevant intergroup differences. In both groups $32 \%$ of patients stopped the concomitant intake of nonsteroidal anti-inflammatory drugs by the end of the study $(p<0.001$, Wilcoxon's test). The number of patients taking steroids decreased from seven to six in the auranofin group and from five to three in the OM-8980 group. The ESR also fell significantly in both groups at months 3 and 6 (Tables 3 and 4, Fig.
1). There was no significant difference in any of the other biological markers of disease activit determined (CRP, latex fixation test, $\mathrm{C} 1 \mathrm{q}$ binding test, IgG, IgM, albumin, cytidine deaminase, $\alpha$ macroglobulin, $\alpha_{1}$ antiproteinase).

\section{TOLER A N C E}

In the OM-8980 group 16 patients $(21 \%)$ reported side effects as compared with 33 patients $(47 \%)$ in the auranofin group $(\mathrm{p}<0 \cdot 01$, Mann-Whitney test: Table 5). Table 6 summarises the type of adverse reactions reported in each treatment group (mainle diarrhoea and stomach upset) and the withdrawals All adverse reactions were reversible after the enc of the treatments. The extensive biochemical toxicology check did not show any consistent abnormality in either group. No problems with leucocytes an\& thrombocytes were encountered.

Table 3 Changes in clinical variables between trial entry and three and six months of treatment

\begin{tabular}{|c|c|c|c|c|c|c|}
\hline Variable & $n$ & Entry & $n$ & Month 3 & $n$ & Month 6 \\
\hline \multicolumn{7}{|l|}{ Ritchie index } \\
\hline OM-8980 & 75 & $\begin{array}{l}27 \cdot 7(12 \cdot 1) \\
(24 \cdot 9-30 \cdot 5)\end{array}$ & 69 & $\begin{array}{l}18.0(8 \cdot 5) \\
(15 \cdot 9-20)\end{array}$ & 61 & $\begin{array}{c}12 \cdot 3(7 \cdot 17) \\
(10 \cdot 4-14 \cdot 1)\end{array}$ \\
\hline Auranofin & 70 & $\begin{array}{l}27 \cdot 3(12 \cdot 7) \\
(24 \cdot 3-30 \cdot 3)\end{array}$ & 61 & $\begin{array}{c}20 \cdot 7(11 \cdot 3) \\
(17 \cdot 9-23 \cdot 6)\end{array}$ & 56 & $\begin{array}{c}15 \cdot 6(10 \cdot 1) \\
(12 \cdot 9-18 \cdot 3)\end{array}$ \\
\hline \multicolumn{7}{|l|}{ Swollen joints } \\
\hline OM-8980 & 74 & $\begin{array}{c}7 \cdot 9(4 \cdot 85) \\
(6 \cdot 8-9 \cdot 0)\end{array}$ & 67 & $\begin{array}{l}6 \cdot 1(3 \cdot 74) \\
(5 \cdot 2-7 \cdot 0)\end{array}$ & 61 & $\begin{array}{l}4 \cdot 1(2 \cdot 77) \\
(3 \cdot 4-4 \cdot 8)\end{array}$ \\
\hline Auranofin & 69 & $\begin{array}{l}7 \cdot 1(4 \cdot 03) \\
(6 \cdot 1-8 \cdot 0)\end{array}$ & 61 & $\begin{array}{l}5 \cdot 9(4 \cdot 53) \\
(4 \cdot 7-7 \cdot 1)\end{array}$ & 56 & $\begin{array}{l}4 \cdot 6(3 \cdot 51) \\
(3 \cdot 7-5 \cdot 6)\end{array}$ \\
\hline \multicolumn{7}{|c|}{ Pain scale $(\mathrm{mm})$} \\
\hline OM-8980 & 75 & $\begin{array}{c}71 \cdot 0(15 \cdot 1) \\
(67 \cdot 6-74 \cdot 5)\end{array}$ & 69 & $\begin{array}{c}49.8(20.4) \\
(44.9-54.7)\end{array}$ & 61 & $\begin{array}{c}34 \cdot 2(19 \cdot 5) \\
(29 \cdot 2-39 \cdot 1)\end{array}$ \\
\hline Auranofin & 70 & $\begin{array}{c}69 \cdot 8(17 \cdot 6) \\
(65.6-74 \cdot 0)\end{array}$ & 61 & $\begin{array}{l}52 \cdot 8(23 \cdot 1) \\
(46 \cdot 9-58 \cdot 7)\end{array}$ & 56 & $\begin{array}{c}39.9(25.9) \\
(32.9-46.8)\end{array}$ \\
\hline \multicolumn{7}{|c|}{ Morning stiffness (min) } \\
\hline OM-8980 & 74 & $\begin{array}{c}93 \cdot 2(64 \cdot 0) \\
(78 \cdot 4-108 \cdot 0)\end{array}$ & 68 & $\begin{array}{c}52 \cdot 6(45 \cdot 5) \\
(41 \cdot 6-63 \cdot 7)\end{array}$ & 58 & $\begin{array}{l}28 \cdot 4(25 \cdot 3) \\
(21 \cdot 8-35 \cdot 1)\end{array}$ \\
\hline Auranofin & 68 & $\begin{array}{c}93 \cdot 8(63 \cdot 8) \\
(78 \cdot 3-109 \cdot 2)\end{array}$ & 59 & $\begin{array}{c}62 \cdot 5(51 \cdot 0) \\
(49 \cdot 2-75 \cdot 8)\end{array}$ & 53 & $\begin{array}{c}47 \cdot 8(48 \cdot 9) \\
(34 \cdot 3-61 \cdot 3)\end{array}$ \\
\hline \multicolumn{7}{|c|}{ Grip strength (atm) } \\
\hline OM-8980 & 71 & $\begin{array}{l}0.40(0.24) \\
(0.34-0.46)\end{array}$ & 69 & $\begin{array}{c}0.43(0.27) \\
(0.37-0.50)\end{array}$ & 59 & $\begin{array}{c}0.51(0.25) \\
(0.44-0.57)\end{array}$ \\
\hline Auranofin & 69 & $\begin{array}{c}0.36(0.22) \\
(0.30-0.41)\end{array}$ & 60 & $\begin{array}{c}0.45(0.24) \\
(0.38-0.51)\end{array}$ & 55 & $\begin{array}{c}0.49(0.26) \\
(0.42-0.56)\end{array}$ \\
\hline \multicolumn{7}{|l|}{$\operatorname{ESR}(\mathrm{mm} / \mathrm{h})$} \\
\hline OM-8980 & 74 & $\begin{array}{c}48 \cdot 7(22 \cdot 1) \\
(43 \cdot 6-53 \cdot 8)\end{array}$ & 67 & $\begin{array}{c}33.4(21.9) \\
(28 \cdot 1-38 \cdot 7)\end{array}$ & 60 & $\begin{array}{l}25 \cdot 7(17 \cdot 8) \\
(21 \cdot 1-30 \cdot 3)\end{array}$ \\
\hline Auranofin & 70 & $\begin{array}{l}50 \cdot 2(25 \cdot 3) \\
(44 \cdot 2-56 \cdot 2)\end{array}$ & 59 & $\begin{array}{l}35 \cdot 8(18 \cdot 2) \\
(31 \cdot 0-40 \cdot 5)\end{array}$ & 56 & $\begin{array}{c}31 \cdot 2(18 \cdot 9) \\
(26 \cdot 1-36 \cdot 2)\end{array}$ \\
\hline
\end{tabular}

${ }^{*}$ Values are means (SD) and the $95 \%$ confidence intervals are shown below in parentheses. Table 4 shows the statistical analysi@ 
Table 4 p Values for Table 3: intragroup changes (in parentheses: intergroup differences) ${ }^{*}$

\begin{tabular}{|c|c|c|}
\hline Variable & Month 3 & Month 6 \\
\hline \multicolumn{3}{|l|}{ Ritchie index } \\
\hline OM-8980 & $<0 \cdot 0001$ & $<0 \cdot 0001$ \\
\hline Auranofin & $\begin{array}{c}<0.0001 \\
(0.06)\end{array}$ & $\begin{array}{r}<0.0001 \\
(0.007)\end{array}$ \\
\hline \multicolumn{3}{|l|}{ Swollen joints } \\
\hline OM-8980 & $<0.0001$ & $<0.0001$ \\
\hline Auranofin & $\begin{array}{c}<0 \cdot 0001 \\
(0 \cdot 12)\end{array}$ & $\begin{array}{c}<0.0001 \\
(0.07)\end{array}$ \\
\hline \multicolumn{3}{|l|}{ Pain scale } \\
\hline OM-8980 & $<0 \cdot 0001$ & $<0 \cdot 0001$ \\
\hline Auranofin & $\begin{array}{l}0.0005 \\
(0 \cdot 37)\end{array}$ & $\begin{array}{c}<0.0001 \\
(0 \cdot 34)\end{array}$ \\
\hline \multicolumn{3}{|c|}{ Morning stiffness } \\
\hline OM-8980 & $<0 \cdot 0001$ & $<0.0001$ \\
\hline Auranofin & $\begin{array}{c}<0 \cdot(0001 \\
(0 \cdot 12)\end{array}$ & $\begin{array}{r}<0.0001 \\
(0.098)\end{array}$ \\
\hline \multicolumn{3}{|l|}{ Grip strength } \\
\hline OM-8980 & 0.012 & $0 \cdot 0001$ \\
\hline Auranofin & $\begin{array}{c}0 \cdot 0008 \\
(0 \cdot 26)\end{array}$ & $\begin{array}{c}<0.0001 \\
(0.72)\end{array}$ \\
\hline \multicolumn{3}{|l|}{ ESR } \\
\hline OM-8980 & $<0 \cdot 0001$ & $<0.0001$ \\
\hline Auranofin & $\begin{array}{c}<0 \cdot 0001 \\
(0.98)\end{array}$ & $\begin{array}{c}<0 \cdot(0001 \\
(0 \cdot 12)\end{array}$ \\
\hline
\end{tabular}

*For tests used see 'Patients and methods'.

\section{Discussion}

The results of the present multicentre double blind trial indicate that OM-8980 and auranofin have a similar beneficial effect in RA. All the usual clinical parameters and the ESR improved significantly. All patients had active disease at the start of the study. Despite a mean disease duration of around eight years, only about $35 \%$ of the patients in both groups had received previous slow acting antirheumatic drugs. They were recruited and treated mainly by rheumatologists in private practice and might have had relatively mild disease.

Although trials in practice reflect the reality of usual patient care, they have the disadvantage of small numbers of patients per investigator. In addition, interobserver variation in clinical assessment is difficult to control. Therefore we did not use absolute values to compare the effect of treatment in the groups but the relative changes during the trial. ${ }^{12}$ Patients had been allocated to treatment groups randomly and were analysed together. Improvement in the Ritchie index was still significant for both groups when the patients from the small centres were omitted from the calculations.

Biological parameters, except the ESR, did not change during the trial. Many of the values were

Table 5 Number of patients with adverse reactions in the two treatment groups

\begin{tabular}{|c|c|c|c|c|c|c|c|c|}
\hline & \multirow[t]{3}{*}{$n$} & \multirow{3}{*}{$\frac{N o}{N o}$} & \multirow{3}{*}{$\begin{array}{l}\text { reaction } \\
\%\end{array}$} & \multicolumn{4}{|c|}{ Adverse reaction } & \multirow{3}{*}{$\begin{array}{l}\text { Mann-Whitney } \\
\text { test }\end{array}$} \\
\hline & & & & \multicolumn{2}{|c|}{$\begin{array}{l}\text { Without } \\
\text { withdrawal }\end{array}$} & \multicolumn{2}{|c|}{$\begin{array}{l}\text { With } \\
\text { withdrawal }\end{array}$} & \\
\hline & & & & No & $\%$ & No & $\%$ & \\
\hline OM-8980 & 75 & 59 & 79 & 8 & 11 & 8 & 11 & $\mathrm{p}<0.01$ \\
\hline
\end{tabular}

Table 6 Type of adverse reactions reported and number of withdrawals because of side effects

\begin{tabular}{|c|c|c|c|c|}
\hline & \multicolumn{2}{|c|}{$O M-8980 \quad(n=75)$} & \multicolumn{2}{|c|}{ Auranofin $(n=70)$} \\
\hline & $\begin{array}{l}\text { Without } \\
\text { withdrawal }\end{array}$ & $\begin{array}{l}\text { With } \\
\text { withdrawal }\end{array}$ & $\begin{array}{l}\text { Without } \\
\text { withdrawal* }\end{array}$ & $\begin{array}{l}\text { With } \\
\text { withdrawal }\end{array}$ \\
\hline Number of patients & 8 & 8 & 24 & 9 \\
\hline Gastrointestinal & 6 & 3 & 20 & 8 \\
\hline Skin & 2 & $3^{* *}$ & 3 & 1 \\
\hline Mucous membranes & 0 & 0 & 2 & 0 \\
\hline Neurological & 2 & 1 & 2 & 0 \\
\hline Various & $2 \dagger$ & $1^{* *} \ddagger$ & $1 \S$ & 0 \\
\hline Laboratory & 0 & $1 \|$ & 0 & 0 \\
\hline
\end{tabular}

${ }^{*}$ Some patients who did not withdraw had more than one side effect; ${ }^{* *}$ withdrawal of one patient with two different side effects. $\dagger$ Palpitations, calf cramps.

$\ddagger$ Bronchospasms.

\$Perspiration.

\|Further increase in transaminases, already raised before study outset. 

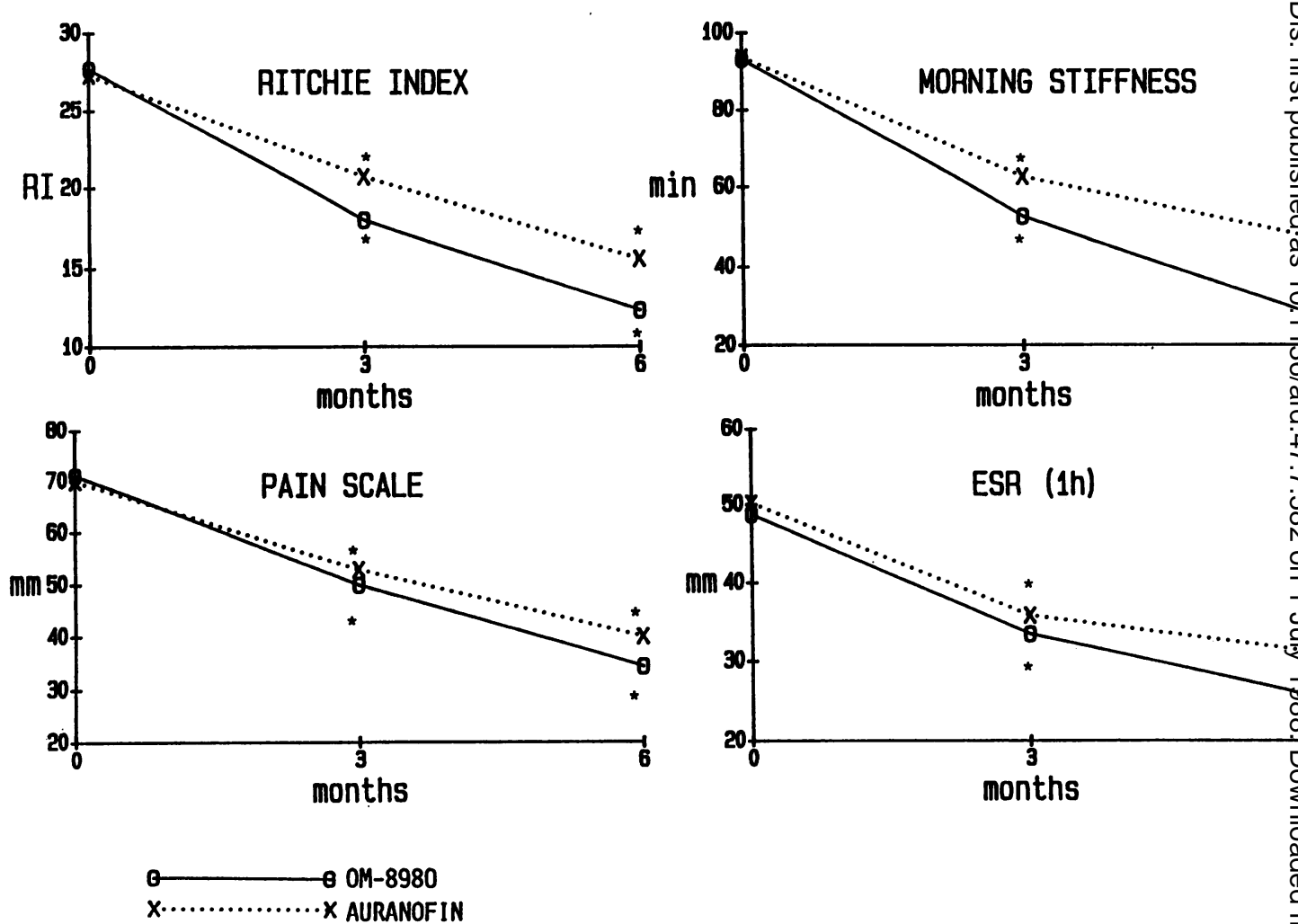

Fig. 1 Evolution of clinical parameters and ESR between start and end of trial with $O M-8980$ and auranofin. ${ }^{*} p<0 \cdot 001$ (intragroup differences).

normal at the start (e.g., CRP). Again, this may reflect relatively mild disease.

The efficacy of auranofin has been documented in many well performed trials, where it has been compared with placebo and other slow acting antirheumatic drugs. ${ }^{13} 14$ The hypothesis that the improvement observed in both groups may reflect the natural course of the disease rather than a beneficial drug effect cannot be refuted totally in the absence of placebo controlled trials with OM-8980. Such studies are presently under way, as is a follow up of most of the patients of this trial under open conditions for a further six month period.

No major adverse reactions were seen in either group. OM-8980 was clearly better tolerated than auranofin mainly owing to less intestinal side effects.

The mode of action of most slow acting antirheumatic drugs is unknown. Different studies of OM-8980 have shown its immunomodulating properties, such as stimulation of $\mathrm{T}$ lymphocytes and inhibition of antibody dependent cytotoxicity. ${ }^{15} 16$ Unpublished reports indicate that treatment of mice with OM-8980 increases resistance to certain infe tions and accelerates carbon clearance. In vitro, 政 increases the antigen presentation capacity of he man macrophages. In which way these results ca be related to the drug's potential activity as ag antirheumatic drug remains to be seen.

We thank Dr P Thompson. Bone and Joint Unit, the Lond Hospital, for determination of cytidine deaminase.

\section{References}

1 Bahous I, Rosenthal M. Basic treatment of rheumatoid arthrifio with an immunomodulating agent at 2 distinct dosage regimens. a double-blind clinical study. International Journal of trit munotherapy. 1987; 3: 265-70.

2 Keller R, Hinz G. Die Wirkung eines oralen polyvalente् Bakterienlysates (BRONCHO-VAXOM) bei chronischen Bronchitis. Prax Klin Pneumol 1984; 38: 225-8.

3 Messerli C, Michetti F, Sauser-Hall P, et al. Effet d'un lys bactérien (BRONCHO-VAXOM) dans le traitement de $\mathbb{P}$ bronchite chronique: essai clinique en double-aveugle m胥 ticentre. Rev Med Suisse Romande 1981; 101: 143-6.

4 Capell H A, Cole D S, Manghani K K, Morris R W. Auranofi Proceedings of a Smith Kline \& French International Symp sium, Amsterdam, Nov 15-16, 1982. Amsterdam: Excerpta Medica, 1983. (Current Clinical Practice Series.) 
5 Ropes M W. Bennett G A, Cobb S, Jacox R, Jessar R A. 1958 Revision of diagnostic criteria for rheumatoid arthritis. Arthritis Rheum 1959; 2: 16-20.

6 Ritchie D M, Boyle J A, McInnes J M, et al. Clinical studies with an articular index for the assessment of joint tenderness in patients with rheumatoid arthritis. $Q J$ Med 1968; 37: 393-406.

7 Huskisson E C. Measurement of pain. Lancet 1974; ii: 1127-31.

8 Rheims M S, McCoy F W, Burrell R G, Buehler F V. Modification of latex-fixation test for study of RA. J Lab Clin Med 1957; 50: 113-8.

9 Zubler R H, Nydegger U, Perrin L H, et al. Circulating and intra-articular immune complexes in patients with rheumatoid arthritis. Correlation of ${ }^{125} \mathrm{I}-\mathrm{Clq}$ binding activity with clinical and biological features of the disease. J Clin Invest 1976; 57: 1308-19.

10 Thompson P W, Jones D D, Currey H L F. Cytidine deaminase activity as a measure of acute inflammation in rheumatoid arthritis. Ann Rheum Dis 1986; 45: 9-14.

11 Vischer T L, Bänziger A E. Quantitative determination of antiglobulins of the IgG, IgA, and IgM class in sera of patients with rheumatoid arthritis or chronic liver disease and of healthy persons. Revue Europeenne d'Etudes Cliniques et Biologiques 1972; 17: 422-5.

12 Lewi P J, Symoens J, Levamisole in rheumatoid arthritis-a multivariate analysis of a multicentric study. J Rheumatol 1978; 5 (suppl 4): 17-25.

13 Wenger M E, Alexander S, Bland J H, Blechman W J. Auranofin versus placebo in the treatment of rheumatoid arthritis. Am J Med 1983; 75 (suppl): 123-7.

14 Ward J R, Williams H J, Egger M J, et al. Comparison of auranofin, gold sodium thiomalate, and placebo in the treatment of rheumatoid arthritis. Arthritis Rheum 1983; 26: 1303-15.

15 Rosenthal M. Effect of a bacterial extract on cellular and humoral immune responses in humans. $J$ Immunopharmacol 1986; 8: $315-25$.

16 Podleski W K. Selective inhibition of antibody-dependent allergic autocytotoxicity by $\mathrm{OM}-89$ in patients with bronchial asthma and urticaria having food allergy toward wheat. Int $J$ Immunopharmacol 1987; 9: 340-53. 